\title{
Trends in the Incidence of Acute Hepatitis B in the Polish Population and Their Determinants
}

\author{
Barbara Stawinska-Witoszynska ${ }^{1}$, Jan Klos ${ }^{2}$, Waclaw Moryson ${ }^{1, *}$ D and Barbara Wieckowska ${ }^{3}$ (D) \\ 1 Department of Epidemiology and Hygiene, Chair of Social Medicine, Poznan University of Medical Sciences, \\ Rokietnicka 4, 60-806 Poznan, Poland; bwitoszynska@ump.edu.pl \\ 2 Department of Public Health, Chair of Social Medicine, Poznan University of Medical Sciences, Rokietnicka 4, \\ 60-806 Poznan, Poland; klos@ump.edu.pl \\ 3 Department of Computer Science and Statistics, Poznan University of Medical Sciences, Rokietnicka 4, \\ 60-806 Poznan, Poland; basia@ump.edu.pl \\ * Correspondence: waclawmoryson@onet.eu
}

Citation: Stawinska-Witoszynska, B.; Klos, J.; Moryson, W.; Wieckowska, B. Trends in the Incidence of Acute Hepatitis B in the Polish Population and Their Determinants. Medicina 2021, 57, 738. https://doi.org/ 10.3390/medicina57080738

Academic Editor: Rinaldo Pellicano

Received: 4 July 2021

Accepted: 20 July 2021

Published: 22 July 2021

Publisher's Note: MDPI stays neutral with regard to jurisdictional claims in published maps and institutional affiliations.

Copyright: (c) 2021 by the authors. Licensee MDPI, Basel, Switzerland. This article is an open access article distributed under the terms and conditions of the Creative Commons Attribution (CC BY) license (https:// creativecommons.org/licenses/by/ $4.0 /)$.

\begin{abstract}
Introduction: The World Health Assembly adopted the Global Health Strategy and aims to reduce the incidence of Hepatitis from up to 10 million cases per year to 0.9 million cases and to reduce deaths from 1.4 million to 0.5 million per year by 2030. However, given the prevalence of chronic Hepatitis B in many countries and the incidence of new cases of acute Hepatitis B, the task is not easy. This study investigates the trends and determinants of the incidence of acute Hepatitis B in Poland in 2005-2019. Materials and Methods: Data on the incidence of acute hepatitis B (AHBV) were obtained from the National Institute of Public Health. A case definition for AHBV was consistent with the EU definition. The incidence trends were determined by considering the sex, age and place of residence. Due to the exponential dependence model, the computations were based on the logarithm of the incidence rate. This allowed for the transformation to linear form and analysis could be conducted using linear models. Pearson's correlation was used to determine the linear trend of incidence in general and according to sex and place of residence. The values of incidence rates (independent proportions test) and the coefficients illustrating the trends under study were also compared among males and females as well as urban and rural residents. Results: The incidence of AHBV in the Polish population decreased with similar slopes in both sexes. The newly reported cases of AHBV were more frequent in the male population. The incidence of acute Hepatitis B in the urban population was significantly higher than in the rural population. The significant decreasing trends in incidence were observed in all age ranges, with the exception of two age ranges $0-4$ and 10-14, where the total incidence during the whole study period was negligible. Conclusion: Despite the significant decrease in the incidence of AHBV in Poland and its position among the European countries with the lowest hepatitis B (HBV) incidence, the alarmingly high proportion of iatrogenic infections requires further improvement in the sanitary condition of health care facilities. It is also necessary to decrease the number of unvaccinated individuals.
\end{abstract}

Keywords: hepatitis; incidence; epidemiology

\section{Introduction}

Over the past 18 months, COVID-19 has dominated other infectious diseases in terms of scope, incidence and mortality rates. Some of them, however, such as the Hepatitis $B$ virus, remain a major global health problem [1-5]. The level of total Hepatitis B incidence in Poland is currently influenced by chronic hepatitis [6,7]. A steady upward trend in the number of reported new chronic Hepatitis has been observed in many European Union/European Economic Area (EU/EEA) countries since 2008 [8,9].

Despite the introduction of mass vaccination and other preventive measures, the problem of acute Hepatitis $B(A H B V)$ remains an ongoing and unresolved issue due to the lack of complete immunisation of children $(85 \%$ of infants vaccinated with three 
doses worldwide) and new infections in unvaccinated or under-vaccinated groups [10]. In 2016, the World Health Assembly adopted the Global Health Sector Strategy (GHSS) to eliminate viral Hepatitis by 2030. The World Health Organization's GHSS aims to reduce the incidence of Hepatitis from 6-10 million cases per year to 0.9 million cases and to reduce hepatitis B (HBV)-related deaths from 1.4 million to 0.5 million per year by 2030 [11,12]. Reaching this aim, however, is not going to be easy.

The aim of this study was to determine the trends in the incidence of acute Hepatitis B in Poland in 2005-2019 and their determinants.

\section{Materials and Methods}

Hepatitis B is a notifiable disease controlled by TESSy-the European epidemiological surveillance system. The author of the study used National Institute of Public HealthNational Institute of Hygiene (NIPH- PZH) data on the incidence of acute Hepatitis B quoted in the "Infectious Diseases and Poisoning in Poland" bulletins that are published annually [11]. The information concerning newly registered cases was reported to the Epidemiology Department of NIPH- PZH by voivodeship epidemiological surveillance offices.

In Poland, a definition of an acute form of Hepatitis B was adopted in 2005 for the purpose of epidemiological surveillance, allowing for separate registration of its acute and chronic forms. The compliance of this definition with the case definition introduced by the EU in 2002 allowed comparing data from Poland with those from other countries [13-15]. In 2009, Poland introduced its case definition for acute Hepatitis B that is consistent with the $2008 \mathrm{EU}$ case definition [13,15,16]. In 2014, a definition corresponding to the new European definition of 2012 was adopted, which considered laboratory criteria for the acute forms of the disease and criteria for the chronic or undefined forms $[13,16]$.

From 2005 to 2019, the incidence trends for acute Hepatitis B were determined by sex, age and place of residence of those infected. The number of cases, the population by sex and age and the incidence rates for these variables in each year are not included in this study due to the large volume of the material.

Due to the exponential dependency model, the computations were based on the logarithm of the incidence rate. This allowed the transformation to a linear form and the implementation of the analysis with linear models.

Pearson's correlation coefficient was used to determine the linear trend in the incidence of acute Hepatitis B in the Polish population with respect to the patients' sex and place of residence. The values of incidence rates (independent proportions test) and coefficients illustrating the trends under examination were also compared among males vs. females and urban vs. rural residents.

A significance level of $p<0.05$ was arbitrarily adopted as the criterion of statistical significance. For multiple comparisons, it was modified according to the Bonferroni correction to $p<0.00333$.

The computations were performed using the PQStat v1.6.0 package (PQStat Software, Poznan, Poland).

\section{Results}

In Poland, the number of recorded acute Hepatitis B infections (including hepatitis B virus and hepatitis C virus mixed infections) ranged from 649 in 2005 to 45 in 2019, with crude incidence rates ranging from $1.70 / 100,000$ to $0.12 / 100,000$.

The incidence of acute Hepatitis B in the Polish population showed a significant decreasing trend $(p<0.0001)$, with the rate of decline being higher in the first years included in the study (Figure 1). 


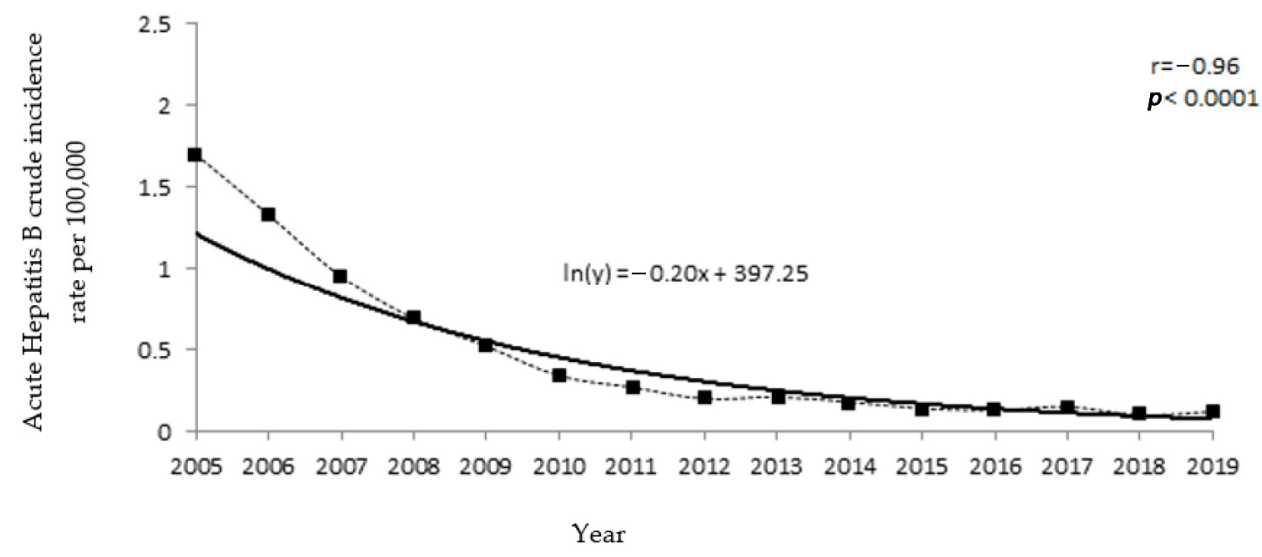

Figure 1. Polish population's acute Hepatitis B incidence trends in 2005-2019.

This phenomenon was the result of significant and very strongly decreasing trends with a similar slope in both sexes $(p<0.0001)$ (Figure 2 and Table 1$)$. Both the strength of the exponential trend and its slope in males and females were not significantly different (Figure 2 and Table 1 ). The newly reported incidence of acute Hepatitis B was significantly higher in the male population $(p<0.0001)$ (Table 1$)$.

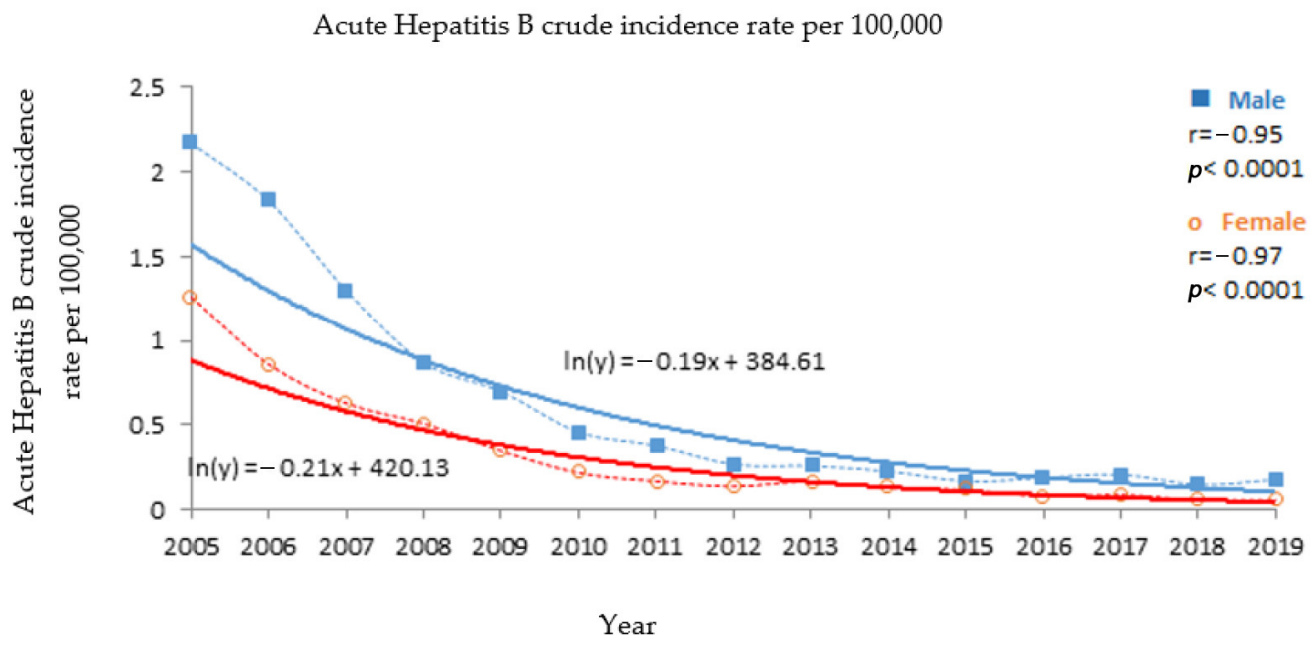

Figure 2. Acute Hepatitis B incidence trends for males and females in Poland, 2005-2019.

Table 1. Comparison of the direction and strength of trends in acute Hepatitis B incidence in Poland according to sex and place of residence, 2005-2019.

\begin{tabular}{ccccccc}
\hline & $\begin{array}{c}\text { Crude Rates } \\
\text { Comparison }\end{array}$ & \multicolumn{3}{c}{ Comparison of the Exponential Time Trends } \\
\cline { 2 - 6 } & Crude Rate & $p$-Value & Slope Coefficient & $p$-Value & $\begin{array}{c}\text { Pearson's Correlation } \\
\text { Coefficient }\end{array}$ & $p$-Value \\
\hline $\begin{array}{c}\text { Female } \\
\text { Male }\end{array}$ & 0.32 & $<0.0001$ & -0.21 & 0.4357 & -0.97 & 0.4537 \\
\hline City & 0.52 & -0.19 & -0.19 & 0.1574 & -0.95 & 0.9764 \\
Village & 0.39 & $<0.001$ & -0.23 & & -0.95 & 0.9764 \\
\hline
\end{tabular}

The incidence of acute Hepatitis B among urban residents was significantly higher than among those living in rural areas $(p<0.0001)$ (Table 1$)$. For both areas of residence, decreasing trends were maintained $(p<0.0001)$ with higher dynamics in the first years of observation (Figure 3). Both trends were very powerful and of a similar slope. The strength of the exponential trend and its slope in the urban and rural populations did not differ significantly (Figure 3 and Table 1). 


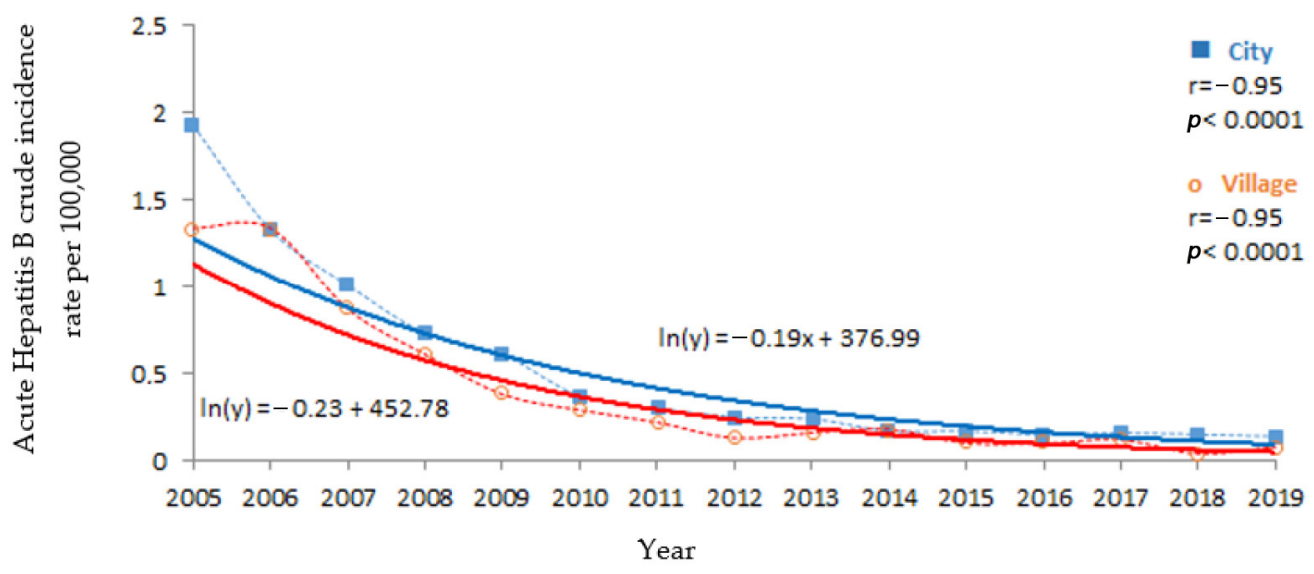

Figure 3. Acute Hepatitis B incidence trends amongst urban and rural residents in Poland, 2005-2019.

Significant decreasing incidence trends were observed in all but two age groups: 0-4 and 10-14 years, in which the total incidence during the whole study period was relatively low (Table 2). In the age group of 5-9 years, the trend could not be determined with only three registered cases of acute Hepatitis B, (Table 2).

Table 2. Linear trend analysis of the incidence of acute Hepatitis B in different age groups in the Polish population in 2005-2019.

\begin{tabular}{clccc}
\hline Age Groups & $\boldsymbol{n}$ & Pearson's Correlation Coefficient & $\begin{array}{c}\text { Slope } \\
\text { Coefficient }\end{array}$ & $p$-Value Benajamini Corected \\
\hline $0-4$ & 6 & -0.50 & -6.68 & 0.3912 \\
$5-9$ & 3 & NA & -3.50 & Too few infected \\
$10-14$ & 19 & -0.91 & -2.59 & 0.1010 \\
$15-19$ & 54 & -0.72 & -2.89 & 0.0224 \\
$20-24$ & 204 & -0.92 & -2.89 & 0.0002 \\
$25-29$ & 298 & -0.90 & -5.80 & 0.00000 \\
$30-34$ & 254 & -0.91 & -3.48 & 0.0010 \\
$35-39$ & 236 & -0.77 & -4.51 & 0.0000 \\
$40-44$ & 190 & -0.92 & -5.08 & 0.0000 \\
$45-49$ & 217 & -0.88 & -3.40 & 0.0003 \\
$50-54$ & 220 & -0.82 & -3.65 & 0.0000 \\
$55-59$ & 204 & -0.94 & -3.23 & 0.0000 \\
$60-64$ & 183 & -0.88 & -4.01 & 0.0000 \\
$65-74$ & 331 & -0.96 & -3.29 & 0.0001 \\
$75+$ & 268 & -0.86 & & \\
\hline
\end{tabular}

The significance level for the $p$-value in the table above was modified according to Bonferroni adjustment and equaled 0.0033 .

\section{Discussion}

In Poland, reporting and recording Hepatitis B infections in clinically symptomatic patients confirmed by laboratory tests began in 1979 and, until 1985, the incidence of Hepatitis B in Poland had been amongst the highest in Europe [17]. In the following years, the number of reported cases decreased, with the largest decrease (88.2\%) between 1993 and 2004 when an intensive programme of prevention and control of Hepatitis B was implemented. Between 1993 and 2004, the value of the total incidence rate of Hepatitis B decreased from 34.6/100,000 to 4.1/100,000 [17]. Between 2005 and 2019, a decrease in newly diagnosed acute Hepatitis $B$ cases was observed and their share in the total incidence of Hepatitis B decreased from $37.6 \%$ to $1.6 \%$ during this period [18].

Between 2006 and 2014 the number of reported acute HBV cases in EU/EEA countries decreased by $56.2 \%$ and the overall incidence rate dropped from 1.6 per 100,000 population to 0.7. This decline was evident in most of the countries regardless of the initial values of incidence coefficients (the highest incidence rate was observed in Bulgaria and Lithuania-6.3/100,000 and 5.1/100,000—respectively), which was the year when the universal vaccination programme was implemented (before or after 1995) or the vaccination 
programme. The level of reduction in HBV incidence was higher in those countries where the universal vaccination programme was implemented earlier. Four countries were not included in this analysis; Italian, Belgian and Croatian data did not allow differentiation between acute and chronic forms of HBV, whereas Liechtenstein did not provide any data. Not all countries showed a decreasing trend over this period; the level of AHBV increased in Austria, Iceland andSpain where this phenomenon was explained by an increase in AHBV among immigrants and in Portugal where the increase was observed in drug addicts and prisoners. Both these countries implemented a universal vaccination programme after 1995, although they did not have a supplementary vaccination programme in place for risk groups [19].

In Italy, which was not included in the above analysis, following the introduction of a compulsory universal vaccination programme in 1991 for newborns and adolescents aged 12, there was a marked decrease in the incidence of acute Hepatitis B in the following years $[20,21]$. Acute HBV incidence rate value fell from 12/100,000 to $0.4 / 100,000$ in 2018 [21]. The decline in prevalence and incidence levels of acute HBV was particularly evident among infants, adolescents and young adults up to 24 years of age [20,21].Since the $\mathrm{HBV}$ vaccination was initiated 30 years ago, it is believed that all vaccinated individuals under the age of 40 are protected against both forms of HBV [21].

According to the European Centre for Disease Prevention and Control (ECDC) 2020 report, the overall incidence trend for acute HBV in the EU/EEA countries showed a steady decline between 2009 and 2018. In 2018, this form of Hepatitis represented only $10 \%$ of HBV cases and chronic Hepatitis B represented $-51 \%$. Twenty-seven countries provided information on AHBV and, considering the 20 countries that systematically reported data from 2009 to 2018, a decrease in the average incidence rate was obtained from 1.0/100,000 population in 2009 to 0.6 in 2018 [20]. In 2018, Poland, with an incidence rate of $0.1 / 100,000$, as well as Finland and France were among the countries with the lowest AHBV incidence [22].

The positive trends of declining incidence of acute Hepatitis B observed in European countries were also reported in many other regions and countries globally, e.g., in South Korea, New Zealand (where only acute HBV is reported) and in Canada [23-25].

In the USA, introducing Hepatitis B vaccination in 1991 resulted in an initial decrease in its incidence. In 2010-2019, the nationwide number of registered new cases of acute Hepatitis B remained stable, while a slight increase in incidence in 2017 in some states was explained by the opioid crisis and improved epidemiological surveillance [26,27].

During the study period, in Poland, the incidence of acute Hepatitis B in men reached a higher level than in women and the rates were 1.4-3 times higher [18], which is consistent with reports from other countries, although not all reports include figures for this ratio. According to data published by ECDC, the overall male-to-female ratio in EU/EEA countries in 2018 was 1.5:1 [22].

Apart from the patients' sex, a factor strongly affecting the prevalence of acute Hepatitis B in Poland was the place of residence, with significantly higher incidence rates among urban dwellers compared to those living in rural areas. Unfortunately, other countries do not publish such data. The only exception is Norway, where the studies on the prevalence of HBV in the years 1992-2009 pointed to the fact that acute Hepatitis B was also diagnosed more frequently among city inhabitants [28]. In Poland, between 2005 and 2019 and in all age groups including those between 15 and $75+$ years of age, the trends in the incidence of acute Hepatitis B showed a significant decrease, which indicates that the improvement in the epidemiological situation was not only the result of a decrease in incidence in groups covered by the mandatory universal vaccination programme. The lack of a significant decrease in incidence in the 0-4 and 10-14 age groups or even the impossibility to determine it among the 5 year olds to 9 year olds is associated with the small sample size.

In 2018, the highest incidence of acute Hepatitis B in Poland was recorded in the age group of 45-49 (0.24 per 100,000) and among those aged 35-39 (0.22 per 100,000), while in the previous year, the highest incidence was found in the age range of 60-64 [7]. In 
2018, 40\% of all acute Hepatitis B cases in EU/EEA countries were reported in the younger population between 25-34 years of age [22]. This was probably due to differences in the main routes of transmission of acute HBV in Poland and EU/EEA countries in general, with heterosexual contacts $(26 \%)$, iatrogenic infections $(19 \%)$ and men who have sex with men (MSM) (14\%) being the most common routes in 2018 [22]. In the same year and in Poland, among patients with a known routes of transmission, iatrogenic infections predominated $60.6 \%(20 / 33)$ followed by sexual contact $(21 \%)$, including three infections in the MSM group [7]. In addition to Poland, high levels of acute HBV incidence associated with health care facilities were also found in Italy and Romania [22].

In the countries where $\mathrm{HBV}$ vaccination was introduced sooner, long-term declining trends in the incidence of Hepatitis B in children, adolescents and young adults were observed sooner than in the other countries [5,20,21,29-31].

In $2019,85 \%$ of infants worldwide received three doses of the Hepatitis B vaccine [32]. In the same year, universal infant vaccination was already being implemented in 49 of the 53 European WHO member states [33]. The level of administration of the birth dose of the vaccine remained uneven. In the WHO African region, it was only $6 \%$ and, when administered in time, it effectively reduced the risk of vertical infections [32].

The long-term decreasing trend in the incidence of AHBV and the place of Poland in the group of European countries with the lowest incidence rate of acute Hepatitis B is encouraging. This is the result of modifications and the expansion of protective vaccination coverage that was initiated in Poland in 1989 when only the newborns and infants born to HBV positive mothers were covered by four doses of vaccination against Hepatitis B [34]. A universal Hepatitis B vaccination programme for all newborns and infants began in 1994-1996, whereas a booster vaccination programme for junior high school students aged 14, covering the children who had not been vaccinated in their first year of life, was implemented in 2000-2011 [34,35].

Apart from universal infant vaccinations, in Poland, mandatory vaccinations were performed for many years for those who were particularly exposed to infection. This included all unvaccinated students of medical schools and other schools providing education in medical faculties; all students of medical universities or other universities providing education in medical faculties; all medical professionals exposed to infection; and all those who were particularly exposed to infection as a result of contact with Hepatitis B positive patients and Hepatitis C positive patients [35,36]. In 2019, that also included those in advanced stage kidney disease with glomerular filtration rates below $30 \mathrm{~mL} / \mathrm{min}$ as well as dialysis patients [36]. Unfortunately, the percentage of newborns who are not inoculated with the first dose of HBV and tuberculosis vaccines has increased alarmingly in recent years $(6.7 \%$ in $2016,10.1 \%$ in 2017) [37].

Most EU/EEA countries and the UK recommend universal childhood HBV vaccination. However, Denmark, Finland and Iceland do not have national universal vaccination policies in place, while universal vaccination is regulated regionally in Sweden [38].

Only the wealthiest countries with low endemicity (HBsAg (surface antigen of the hepatitis $\mathrm{B}$ virus) $<1 \%$ ) have chosen to opt for a selective vaccination programme that applies to people at a high risk of HBV infection, yet the definition of high risk varies amongst countries. The programme includes but is not limited to intravenous drug users and their community, MSM, the individuals exposed to close family contacts with an infected person, health care workers, police officers, firefighters, newborns to mothers with a chronic HBV infection or those with acute Hepatitis B during pregnancy [39].

In Poland, in addition to HBV screening for pregnant women in the third trimester of pregnancy (since 2011), children of HBV-positive mothers, patients requiring chronic haemodialysis treatment and blood donor candidates are screened [40]. Active and passive prophylaxis of vertical HBV infections in Poland consists of administering anti-HBV immunoglobulin and the first dose of HBV vaccine to the newborns of HBV-positive mothers within twelve hours after birth [41]. Blood donor testing is the most common HBV screening test performed in EU/EEA countries [42]. According to ECDC data, in 2016-2017 
in the EU/EEA countries, 15 countries had a national policy that included screening for HIV-infected people. Drug users were screened in 13 countries, 12 countries screened their health workers, 11 countries screened prisoners, 6 countries screened pregnant women and 7 countries screened immigrants [43].

Although, since the 1990s, Poland has achieved significant results in the fight against $\mathrm{HBV}$, there is still much to perform in order to reach the WHO targets for the elimination of viral Hepatitis [11].

\section{Conclusions}

Despite the significant downward trend in the incidence of acute Hepatitis B in Poland and its membership in the group of European countries with its lowest incidence, the alarmingly high proportion of infections associated with health care activities calls for further improvement in the sanitary condition of health care facilities. The number of people who have been immunised needs to be increased and the high level of infant immunisation needs to be maintained.

Author Contributions: Conceptualization, B.S.-W. and J.K.; methodology, B.W., B.S.-W. and J.K.; software, B.W.; validation, B.S.-W. and B.W.; formal analysis, B.W.; investigation, B.S.-W. and J.K.; resources, B.S.-W. and B.W.; data curation, B.W.; writing - original draft preparation, B.S.-W., W.M. and J.K.; writing-review and editing, B.S.-W. and W.M.; visualisation, B.S.-W., J.K. and W.M.; supervision, B.S.-W. All authors have read and agreed to the published version of the manuscript.

Funding: This research received no external funding.

Institutional Review Board Statement: I would like to exclude this statement as this study did not involve humans or animals.

Informed Consent Statement: I would like to exclude this statement as the study did not involve humans.

Data Availability Statement: Data are available in a publicly accessible repository that does not issue DOIs. Publicly available datasets were analyzed in this study. This data can be found here: http://wwwold.pzh.gov.pl/oldpage/epimeld/index_p.html (accessed on 17 May 2021).

Conflicts of Interest: The authors declare no conflict of interest.

\section{References}

1. Madihi, S.; Syed, H.; Lazar, F.; Zyad, A.; Benani, A. A systematic review of the current hepatitis B viral infection and hepatocellular carcinoma situation in Mediterranean countries. BioMed Res. Int. 2020, 2020, 1-16. [CrossRef]

2. Pettersson, J.H.-O.; Myking, S.; Elshaug, H.; Bygdås, K.I.E.; Stene-Johansen, K. Molecular epidemiology of hepatitis B virus infection in Norway. BMC Infect. Dis. 2019, 19, 1-7. [CrossRef] [PubMed]

3. Jefferies, M.; Rauff, B.; Rashid, H.; Lam, T.; Rafiq, S. Update on global epidemiology of viral hepatitis and preventive strategies. World J. Clin. Cases 2018, 6, 589. [CrossRef] [PubMed]

4. Nayagam, S.; Thursz, M. Strategies for global elimination of chronic HBV infection: 2019 update. Curr. Hepatol. Rep. 2019, 18, 300-309. [CrossRef]

5. Hyun Kim, B.; Ray Kim, W. Epidemiology of hepatitis B virus infection in the United States. Clin. Liver Dis. 2018, 12, 1-4. [CrossRef] [PubMed]

6. Wiktor, A.; Borawski, T.; Stẹpień, M. Hepatitis B in Poland in 2017. Przeglad Epidemiol. 2019, 73, 157-166. [CrossRef]

7. Wiktor, A.; Stępień, M. Hepatitis B in Poland in 2018. Przeglad Epidemiol. 2020, 74, 196-208. [CrossRef] [PubMed]

8. European Centre for Disease Prevention and Control. Chronic Hepatitis B Infections on the Rise Since 2008. 2019. Available online: https:/ / www.ecdc.europa.eu/en/news-events/chronic-hepatitis-b-infections-rise-2008 (accessed on 17 May 2021).

9. Hepatitis B Annual Epidemiological Report for 2017; European Centre for Disease Prevention and Control: Stockholm, Germany, 2019.

10. Global Immunization Coverage 2019. 2019. Available online: https://www.who.int/news-room/fact-sheets/detail/ immunization-coverage (accessed on 17 May 2021).

11. Waheed, Y.; Siddiq, M.; Jamil, Z.; Najmi, M.H. Hepatitis elimination by 2030: Progress and challenges. World J. Gastroenterol. 2018, 24, 4959-4961. [CrossRef]

12. Smith, S.; Harmanci, H.; Hutin, Y.; Hess, S.; Bulterys, M.; Peck, R.; Rewari, B.; Mozalevskis, A.; Shibeshi, M.; Mumba, M.; et al. Global progress on the elimination of viral hepatitis as a major public health threat: An analysis of WHO Member State responses 2017. JHEP Rep. 2019, 1, 81-89. [CrossRef] [PubMed] 
13. Definicje Przypadków Chorób Zakaźnych na Potrzeby Nadzoru Epidemiologicznego. 2021. Available online: http://wwwold. pzh.gov.pl/oldpage/epimeld/inne/Def_PL1_3.pdf (accessed on 17 May 2021).

14. Czarkowski, M.P.; Bobel, D. Wirusowe zapalenia watroby typu B w 2006 roku. Przeglad Epidemiol. 2008, 62, 317-324.

15. Duffell, E.F.; van de Laar, M.J. Survey of surveillance systems and select prevention activities for hepatitis B and C, European Union/European Economic Area, 2009. Eurosurveillance 2015, 20, 21080. Available online: https:/ /www.eurosurveillance.org/ content/10.2807/1560-7917.ES2015.20.13.21080 (accessed on 17 May 2021). [CrossRef]

16. Dakic, Z.; Duric, P.; Fabri, M.; O'May, F. Validity of hepatitis B and hepatitis C case definitions. J. Infect. Public Health 2019, 12, 516-521. [CrossRef]

17. Magdzik, W.; Czarkowski, M.P. Sytuacja epidemiologiczna wirusowego zapalenia watroby typu B w Polsce w latach 1979-2004. Przeglad Epidemiol. 2006, 60, 471-480.

18. Choroby Zakaźne i Zatrucia w Polsce, Biuletyny Roczne z lat 2005-2019; Narodowy Instytut Zdrowia Publicznego-Państwowy Zakład Higieny: Warsaw, Poland, 2020.

19. Miglietta, A.; Quinten, C.; Lopalco, P.L.; Duffell, E. Impact of hepatitis B vaccination on acute hepatitis B epidemiology in European Union/European Economic Area countries, 2006 to 2014. Eurosurveillance 2018, 23, 17-00278. Available online: https: / / www.eurosurveillance.org/content/10.2807/1560-7917.ES.2018.23.6.17-00278 (accessed on 17 May 2021). [CrossRef]

20. Sagnelli, E. Epidemiology of acute and chronic hepatitis B and delta over the last 5 decades in Italy. World J. Gastroenterol. 2014, 20, 7635. [CrossRef]

21. Zanella, B.; Bechini, A.; Boccalini, S.; Sartor, G.; Tiscione, E.; Bonanni, P. Hepatitis B seroprevalence in the pediatric and adolescent population of Florence (Italy): An update 27 years after the implementation of universal vaccination. Vaccines 2020, 8, 156. [CrossRef]

22. Hepatitis B Annual Epidemiological Report for 2018; European Centre for Disease Prevention and Control: Stockholm, Germany, 2020; Available online: https://www.ecdc.europa.eu/sites/default/files/documents/HEPB_AER_2018_Report.pdf (accessed on 17 May 2021).

23. Yim, S.Y.; Kim, J.H. The epidemiology of hepatitis B virus infection in Korea. Korean J. Intern. Med. 2019, 34, 945-953. [CrossRef] [PubMed]

24. New Zealand Ministry of Health. Hepatitis B in Immunisation Handbook 2020. 2020. Available online: https:/ / www.health.govt. nz/system/files/documents/pages/immunisation-handbook-2020-9-hepatitis-b-sep20-v4.pdf (accessed on 17 May 2021).

25. Public Health Agency of Canada. Epi-Update: Brief Report: Hepatitis B Infection in Canada. 2011. Available online: https: / / central.bac-lac.gc.ca/.item?id=HP40-40-2011-eng\&op=pdf\&app=Library (accessed on 17 May 2021).

26. Hepatitis-United States, 2017; Centers for Disease Control and Prevention: Atlanta, GA, USA, 2019. Available online: https: //www.cdc.gov/hepatitis/statistics/2017surveillance/index.htm (accessed on 17 May 2021).

27. Viral Hepatitis Surveillance Report 2019—Introduction; Centers for Disease Control and Prevention: Atlanta, GA, USA, 2021. Available online: https://www.cdc.gov/hepatitis/statistics/2019surveillance/Introduction.htm (accessed on 17 May 2021).

28. Rimšelienè, G.; Nilsen, Ø.; Kløvstad, H.; Blystad, H.; Aavitsland, P. Epidemiology of acute and chronic hepatitis B virus infection in Norway, 1992-2009. BMC Infect. Dis. 2011, 11, 1-7. [CrossRef] [PubMed]

29. Nelson, N.P.; Easterbrook, P.J.; McMahon, B.J. Epidemiology of hepatitis B virus infection and impact of vaccination on disease. Clin. Liver Dis. 2016, 20, 607-628. [CrossRef] [PubMed]

30. Al-Jubran, K.M.; Al-Dossary, M.A.; Elsafi, S.H. The declining rates of hepatitis B carriage among adolescents and young people in the Eastern region of Saudi Arabia. Saudi Med. J. 2016, 37, 864-870. [CrossRef] [PubMed]

31. Su, W.J.; Liu, C.C.; Liu, D.P.; Chen, S.F.; Huang, J.J.; Chan, T.C.; Chang, M.H. Effect of age on the incidence of acute hepatitis B after 25 years of a universal newborn hepatitis B immunization program in Taiwan. J. Infect. Dis. 2012, 205, 757-762. [CrossRef]

32. Hepatitis B Key Facts; World Health Organization: Geneva, Switzerland, 2021; Available online: https://www.who.int/newsroom/fact-sheets/detail/hepatitis-b (accessed on 17 May 2021).

33. Hepatitis B in the WHO European Region; World Health Organization: Geneva, Switzerland, 2019; Available online: https: //www.euro.who.int/_data/assets/pdf_file/0007/377251/Fact-Sheet-Hepatitis-B_2019-ENG.pdf (accessed on 17 May 2021).

34. Magdzik, W.; Czarkowski, M.P. Stan zaszczepienia przeciwko wirusowemu zapaleniu watroby typu B w Polsce do końca 2004 roku. Przeglad Epidemiol. 2006, 60, 185-192.

35. Komunikat Głównego Inspektora Sanitarnego z Dnia 17 Października 2011 r. w Sprawie Programu Szczepień Ochronnych na rok 2011. 2011. Available online: https://sip.lex.pl/akty-prawne/dzienniki-resortowe/program-szczepien-ochronnych-na-rok2011-34524903 (accessed on 17 May 2021).

36. Komunikat Głównego Inspektora Sanitarnego z Dnia 25 Października 2018 r. w Sprawie Programu Szczepień Ochronnychnarok 2019. 2018. Available online: http:/ / dziennikmz.mz.gov.pl/legalact/2018/104/ (accessed on 17 May 2021).

37. Nitsch-Osuch, A.; Pawlus, B.; Pawlak, M.; Kuchar, E. Decreasing Vaccination Coverage Against Hepatitis B and Tuberculosis in Newborns. Trends Biomed. Res. 2019, 99-105. Available online: http://link.springer.com/10.1007/5584_2019_446 (accessed on 17 May 2021).

38. European Centre for Disease Prevention and Control. Monitoring the Responses to Hepatitis B and C Epidemics in EU/EEA Member States, 2019; European Centre for Disease Prevention and Control: Stockholm, Germany, 2020; Available online: https: / / data.europa.eu/doi/10.2900/034039 (accessed on 17 May 2021). 
39. World Health Organization. European Vaccine Action Plan 2015-2020 Midterm Report; World Health Organization: Copenhagen, Danmark, 2018; Available online: https://www.euro.who.int/_data/assets/pdf_file/0007/381184/evap-midterm-report-eng. pdf (accessed on 17 May 2021).

40. Narodowy Instytut Zdrowia Publicznego Państwowy Zakład Higieny. Profilaktyka Wirusowego Zapalenia Wątroby Typu B i C 2021. Available online: https:/ / watrobanieboli.pzh.gov.pl/profilaktyka-wirusowego-zapalenia-watroby-typu-b-i-c/ (accessed on 17 May 2021).

41. Pawłowska, M.; Sobolewska-Pilarczyk, M. Rekomendacje postępowania w profilaktyce wertykalnych zakażeń HBV i HCV. Przeglad Epidemiol. 2016, 70, 119-120.

42. Lieshout-Krikke, R.W.; Domanovic, D.; de Kort, W.; Mayr, W.; Liumbruno, G.M.; Pupella, S.; Kurz, J.; Knutson, F.; MacLennan, S.; Folléa, G. Selection strategies for newly registered blood donors in European countries. Blood Transfus. 2017, 15, 495. [CrossRef] [PubMed]

43. Hepatitis B and C Testing in the EU/EEA: Progress in Reaching the Elimination Targets; European Centre for Disease Prevention and Control: Stockholm, Germany, 2021. 